CZASOPISMO INŻYNIERII LĄDOWEJ, ŚRODOWISKA I ARCHITEKTURY JOURNAL OF CIVIL ENGINEERING, ENVIRONMENT AND ARCHITECTURE

JCEEA, t. XXXIV, z. 64 (1/17), styczeń-marzec 2017, s. 317-334, DOI:10.7862/rb.2017.30

\author{
Michał BETLEJ ${ }^{1}$ \\ Henryk CIUREJ ${ }^{2}$ \\ Edyta PIECIORAK ${ }^{3}$
}

\title{
WPLYW WIELKOŚCI GEOMETRYCZNYCH NA CZĘSTOTLIWOŚCI DRGAŃ WŁASNYCH KOMPOZYTOWEGO DYFUZORA LAMINATOWEGO
}

\begin{abstract}
Przedmiotem niniejszej pracy jest analiza modalna kompozytowego dyfuzora laminatowego. Konstrukcje tego typu wykorzystuje się w przemysłowej technologii chłodzenia wody. Wewnątrz dyfuzora wiruje śmigło wytwarzając sztuczny ciąg powietrza. Z uwagi na łatwość wykonania, odporność chemiczną oraz trwałość dyfuzory produkuje się jako samonośne powłoki kompozytowe, najczęściej na bazie poliestrów zbrojonych włóknami szklanymi (FRP). Istotnym problemem projektowania dyfuzorów jest ograniczenie amplitud drgań wywoływanych wirującymi bryłami ciśnienia generowanymi przez poruszające się końcówki łopat wirnika. Jednym ze sposobów ograniczenia amplitud drgań jest odpowiednie dostrojenie częstotliwości i postaci drgań własnych powłoki dyfuzora względem częstotliwości wymuszenia. Celem niniejszej pracy jest określenie wpływu wybranych parametrów geometrycznych (kształtu) na częstotliwości drgań własnych powłoki dyfuzora. Zbudowano parametryczny model MES. Zastosowano trzy- i czterowęzłowe elementy powłoki kompozytowej; odtworzono układ warstw kompozytu, a także złożony kształt powłoki zewnętrznej wraz z usztywnieniami. W pracy przedstawiono wybrane wyniki obliczeń, zestawiono parametry determinujące częstotliwości i postacie drgań własnych oraz sformułowano wnioski. Otrzymane rezultaty można wykorzystać w projektowaniu przedmiotowych konstrukcji.
\end{abstract}

Słowa kluczowe: dyfuzor FRP, drgania własne, powłoka kompozytowa

\footnotetext{
${ }^{1}$ Autor do korespondencji / corresponding author: Michał Betlej, AGH Akademia Górniczo-Hutnicza, Wydział Górnictwa i Geoinżynierii, Katedra Geomechaniki, Budownictwa i Geotechniki, 30-059 Kraków, Al. Mickiewicza 30, tel. +48 12 6174772; mbetlej@agh.edu.pl

${ }^{2}$ Henryk Ciurej, AGH Akademia Górniczo-Hutnicza, Wydział Górnictwa i Geoinżynierii, Katedra Geomechaniki, Budownictwa i Geotechniki, 30-059 Kraków, Al. Mickiewicza 30, tel. +48 12 6174772; hciurej@agh.edu.pl

${ }^{3}$ Edyta Pięciorak, AGH Akademia Górniczo-Hutnicza, Wydział Górnictwa i Geoinżynierii, Katedra Geomechaniki, Budownictwa i Geotechniki, 30-059 Kraków, Al. Mickiewicza 30, tel. +48 12 6172128; epiec@agh.edu.pl
} 


\section{Wprowadzenie}

Przedmiotem niniejszej pracy jest kompozytowy dyfuzor laminatowy (Rys. 1). Konstrukcje tego typu są elementem technologii chłodzenia gorącej wody wykorzystywanej następnie w innych procesach przemysłowych.

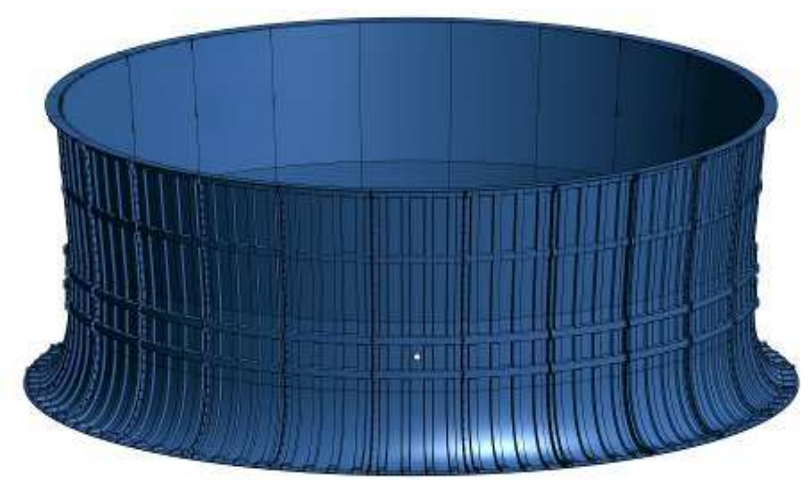

Rys. 1. Widok powłoki dyfuzora laminatowego z widocznymi wzmocnieniami powłoki zewnętrznej - ryflami obwodowymi i południkowymi [1]

Fig. 1. View of composite fan stack (diffusor) strengthened by circumferential and longitudinal ribbons [1]

Zasada chłodzenia jest identyczna jak w konwencjonalnych chłodniach kominowych lecz tu ciąg wywoływany jest sztucznie, a nie grawitacyjnie; ponadto dyfuzory umieszcza się na dachach budynków chłodni, które są najczęściej konstrukcjami szkieletowymi wzniesionymi na planie prostokąta - Rys. 2. Wytworzony przez wentylator ciąg jest przeciwbieżny w stosunku do ruchu kropel cieczy opadających w dół wewnątrz budynku chłodni.

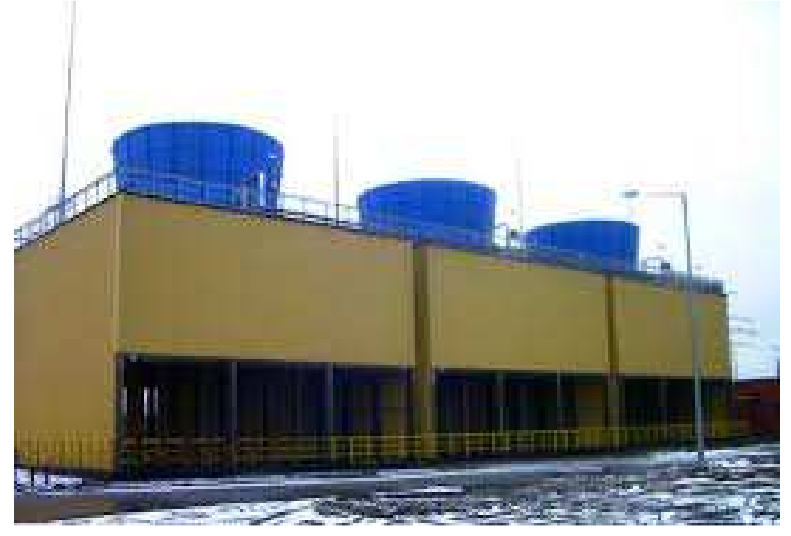

Rys. 2. Widok budynku chłodni wentylatorowej. Na dachu widoczne powłoki dyfuzorów [2]

Fig. 2. View of building of fan cooling. The fan stacks were placed on the roof [2] 
Historycznie konstrukcje dyfuzorów, jako elementów chłodni wentylatorowych, wznoszono ze zbrojonego betonu, stali (cienka powłoka metalowa wzmocniona zewnętrzną konstrukcją kratowo-ramową) lub z drewna. Były to konstrukcje sztywne i ciężkie - stanowiły zatem istotne obciążenie stropów. Obecnie, od wielu lat, dyfuzory wykonuje się jako lekkie, samonośne powłoki kompozytowe, zwykle na bazie epoksydu zbrojonego matami lub tkaninami szklanymi (FRP) - rzadziej, z uwagi na uwarunkowania ekonomiczne, zbrojonego tkaninami na bazie włókien węglowych [3]. Ponadto istotne zmniejszenie masy dyfuzorów pozwala projektować układy nośne samych budynków chłodni z elementów kompozytowych np. kształtowników kompozytowych produkowanych metodą pultruzji.

Dyfuzor jest powłoką osiowo symetryczną składającą się najczęściej z trzech części (Rys. 3): $1^{\circ}$ napływowej w kształcie ściętej elipsoidy obrotowej; $2^{\circ}$ walcowej, w poziomie której wiruje wentylator, wymuszający ciąg powietrza skierowanego w górę; $3^{\circ}$ wylotowej w kształcie odwróconego, ściętego stożka.

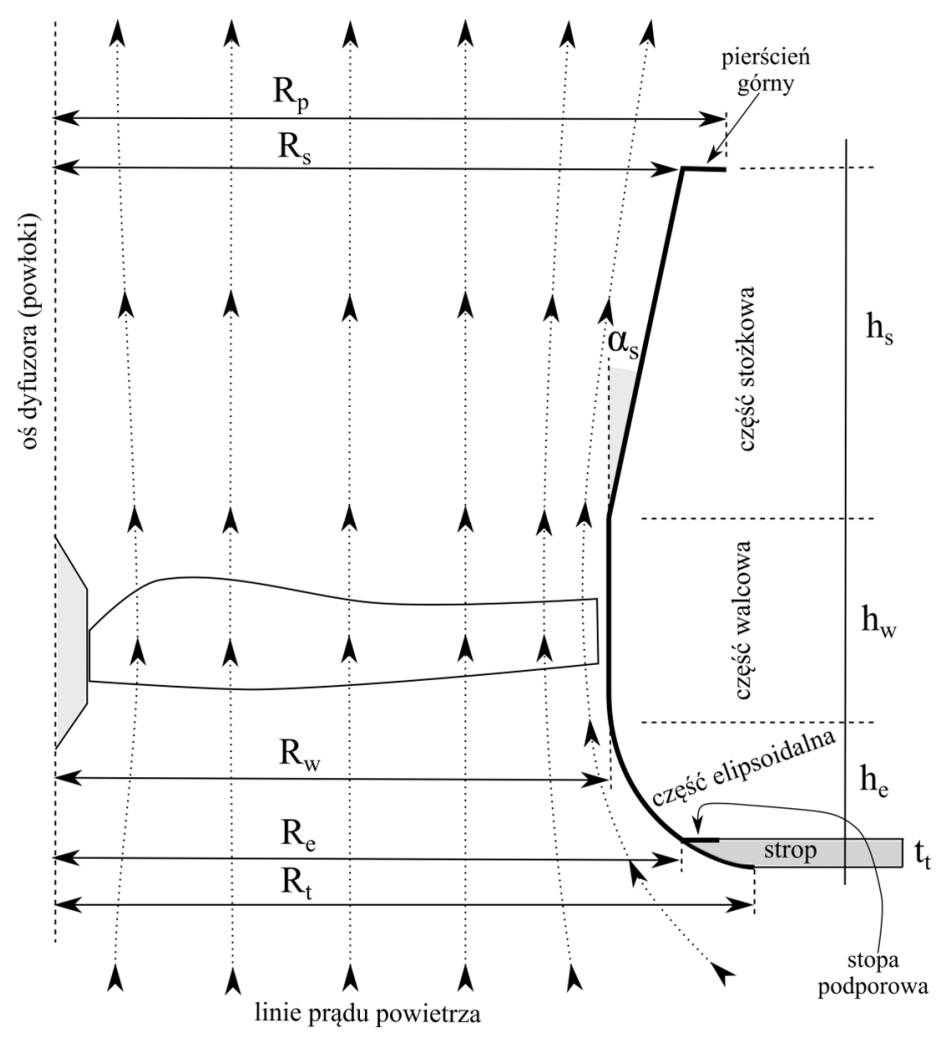

Rys. 3. Schemat konstrukcji dyfuzora, podział na części oraz podstawowe parametry geometryczne powłoki

Fig. 3. Illustration of fan stack shell with basic geometric parameters and split into parts 
Z fizycznego punktu widzenia dyfuzor jest odwróconą dyszą tzn. powietrze przepływa (z prędkością podkrytyczną) z przekroju o mniejszej średnicy w kierunku większego przekroju - Rys. 3 (zob. [3]). Następuje tu więc zmniejszenie prędkości przepływu powietrza i zwiększenie jego ciśnienia. Nie mniej, z uwagi na ruch powietrza wewnątrz powłoki, panujące tam ciśnienie jest mniejsze niż to na zewnątrz - stąd powłoka obciążona jest stałym podciśnieniem, zależnym m.in. od prędkości przepływu powietrza i geometrii dyfuzora.

Na Rys. 3 przedstawiono schemat konstrukcji dyfuzora, wspomniany wcześniej podział na części oraz podstawowe parametry geometryczne. Zasadniczym wymiarem jest promień części walcowej $\mathrm{R}_{\mathrm{w}}$, w poziomie której wirują łopaty wentylatora. Jest to najczęściej 3-7 łopat o złożonym profilu geometrycznym. Poniżej części walcowej znajduje się elipsoida obrotowa (najczęściej ścięta), która zapewnia laminarny napływ powietrza na łopaty wirnika. Na górnej powierzchni stropu formuje się stopę podporową połączoną z elipsoidą. Stopę przykręca się śrubami do stropu. Jest ona elementem przenoszącym wszystkie obciążenia z dyfuzora na konstrukcję wsporczą. Całość układu powinna być tak złożona, aby tworząca elipsoidy wchodziła po stycznej poziomej na dolną powierzchnię stropu i po stycznej pionowej do tworzącej walca. W części wylotowej (stożkowej) tworząca odchylona jest od osi walca o kąt $\alpha_{s}=5^{\circ} \div 7^{\circ}$; wylot stożka kończy się płaskim pierścieniem lub/i dodatkowym ryflem. Geometria stożka wylotowego $\mathrm{w}$ istocie jest determinowana warunkami aerodynamiki przepływu [3].

Jak widać z Rys. 1 cała konstrukcja powłoki jest podzielona po obwodzie na pojedyncze panele - ich liczba zależy m.in. od promienia $R_{w}$ i technologii produkcji. Panele łączy się poprzez specjalnie ukształtowane żebra łączące, skręcane za pomocą śrub; pomiędzy te żebra wkłada się uszczelki gumowe aby zapewnić szczelność połączenia. Ostatecznie dyfuzor kompozytowy pozostaje złożoną konstrukcją powłokowo-żebrową o zmiennej sztywności, zarówno w kierunku obwodowym, jak i południkowym.

Do podstawowych obciążeń, które należy uwzględnić przy projektowaniu powłok dyfuzorów należą: ciężar własny, wiatr, podciśnienie wewnętrzne oraz wirujące bryły ciśnień (podążające za końcami łopat i działające na wewnętrzną ścianę powłoki) [4,5]. Ostatnie obciążenie jest obciążeniem ruchomym, bezinercyjnym, o złożonym kształcie przestrzennym. Jego obecność stanowi zasadniczą trudność w analizie i projektowaniu dyfuzorów laminatowych (kompozytowych), jest bowiem czynnikiem wywołującym drgania powłoki o złożonym charakterze i przebiegu. Do rzadziej uwzględnianych obciążeń należą: śnieg, oblodzenie lub/i wymuszenie sejsmiczne [3,9].

$\mathrm{Z}$ projektowego punktu widzenia zwykle nie ma problemu ze spełnieniem warunków nośności od podstawowych obciążeń i ich kombinacji, ponieważ wytrzymałość materiałów kompozytowych na bazie standardowych mat i tkanin szklanych jest wystarczająca lecz moduły sprężystości są względnie niskie. Dlatego też, jak dowodzi praktyka, warunkami wymiarującymi są wymagania użyt- 
kowe powłoki. W szczególności jest to nieprzekroczenie dopuszczalnych całkowitych przemieszczeń powłoki, a zwłaszcza deplanacji radialnej części walcowej (owalizacji rozumianej jako odstępstwo od kształtu okręgu). Nadmierna owalizacja złożona $\mathrm{z}$ translacją poziomą może doprowadzić w skrajnym przypadku do zetknięcia się wirujących końców łopat śmigła z powłoką, co skutkowałoby jej uszkodzeniem lub zniszczeniem. Tak więc w projektowaniu nie da się uniknąć nałożenia efektów statycznych i dynamicznych (chwilowych).

Odpowiedniej sztywności obwodowej i południkowej powłoki, koniecznej do ograniczenia amplitud przemieszczeń, poszukuje się na drodze wprowadzenia zewnętrznych usztywnień w postaci żeber, ryfli, kołnierzy itp. - zob. Rys. 1. Jednym z podstawowych sposobów ograniczenia amplitud drań powłoki dyfuzorów jest odsunięcie częstotliwości jej drgań własnych $f_{i}$ od kolejnych częstotliwości wymuszenia $v_{j}$ danych wzorem (zob.[3]):

$$
v_{1}=n / 60, \quad v_{j}=N_{L} n(j-1) / 60 \quad j>1
$$

gdzie: $n$ - liczba obrotów wirnika na minutę, $N_{L}$ - liczba łopat wirnika, $j$ - kolejna harmoniczna wymuszenia.

\section{Przedmiot i cel analizy}

Przedmiotem niniejszego artykułu jest dyfuzor laminatowy o promieniu części walcowej $R_{\mathrm{w}}=3.5 \mathrm{~m}$ i jej wysokości $\mathrm{h}_{\mathrm{w}}=1.2 \mathrm{~m}$. Wysokość części stożkowej wynosi $h_{s}=4 m$, zaś części eliptycznej $h_{e}=1.1 \mathrm{~m}$, grubość stropu pod stopą dyfuzora wynosi $\mathrm{t}_{\mathrm{t}}=0.3 \mathrm{~m}$. Po obwodzie dyfuzor składa się z $N=24$ identycznych paneli, wobec tego kąt panelu wynikający z podziału wynosi $\alpha_{N}=360 / N=15^{\circ}$. Panele łączy się poprzez skręcenie żeber łączących. Na Rys. 4 pokazano przekrój podłużny przez środek panelu oraz przekrój poprzeczny panelu przez część walcową.

W części walcowej ukształtowano dwa ryfle obwodowe, których osie odległe są o $\left(\mathrm{h}_{\mathrm{w}}+\mathrm{a}\right) / 3$, natomiast w części stożkowej ukształtowano jeden ryfel obwodowy odległy wzdłuż tworzącej stożka o e s $_{\mathrm{s}}$ od szczytu powłoki. Długość tworzącej stożka wynosi $l_{\mathrm{s}}=\mathrm{h}_{\mathrm{s}} / \cos \left(\alpha_{\mathrm{s}}\right)$, gdzie kąt odchylenia tworzącej stożka od pionu wynosi $\alpha_{\mathrm{s}}=7^{\circ}$. Po wysokości panelu ukształtowano również dwa ryfle, których osie odchylono o kąt $\alpha_{N} / 4$ od żeber łączących. Szerokość pierścienia górnego wynosi $\mathrm{e}_{\mathrm{p}}$. $\mathrm{Z}$ powodów technologicznych kąt $\beta$ odchylenia ściany ryfla wynosi $7^{\circ}$, skutkiem tego opis geometrii przekroju poprzecznego ryfla zależy jedynie od jego wysokości $h_{r}$ i szerokości podstawy a. $Z$ kolei wysokość żeber łączących panele jest uzależniona od wysokości ryfli i wynosi $\mathrm{h}_{\mathrm{z}}=\mathrm{h}_{\mathrm{r}}+20 \mathrm{~mm}$.

Celem niniejszego artykułu jest zbadanie wpływu wybranych parametrów geometrycznych powłoki na częstotliwości $f_{i}$ i postacie drgań własnych $\Phi_{i}$ dyfuzora. $\mathrm{Z}$ uwagi na fakt, że konstrukcja jest osiowo symetryczna, występują tu po- 
dwójne częstości drgań własnych - jednej wartości częstości odpowiadają dwie różne, ortogonalne postacie drgań. O ile analiza wpływu poszczególnych parametrów na częstotliwości mogłaby być przeprowadzona przez dostępne na rynku oprogramowanie MES z zastosowaniem analizy wrażliwości, to niestety, gdy chodzi o postacie drgań i ich pochodne możliwości są ograniczone. Stąd też autorzy zdecydowali się na obserwację zmian częstotliwości i postaci własnych poprzez analizę dyskretnych zbiorów wartości parametrów swobodnych.
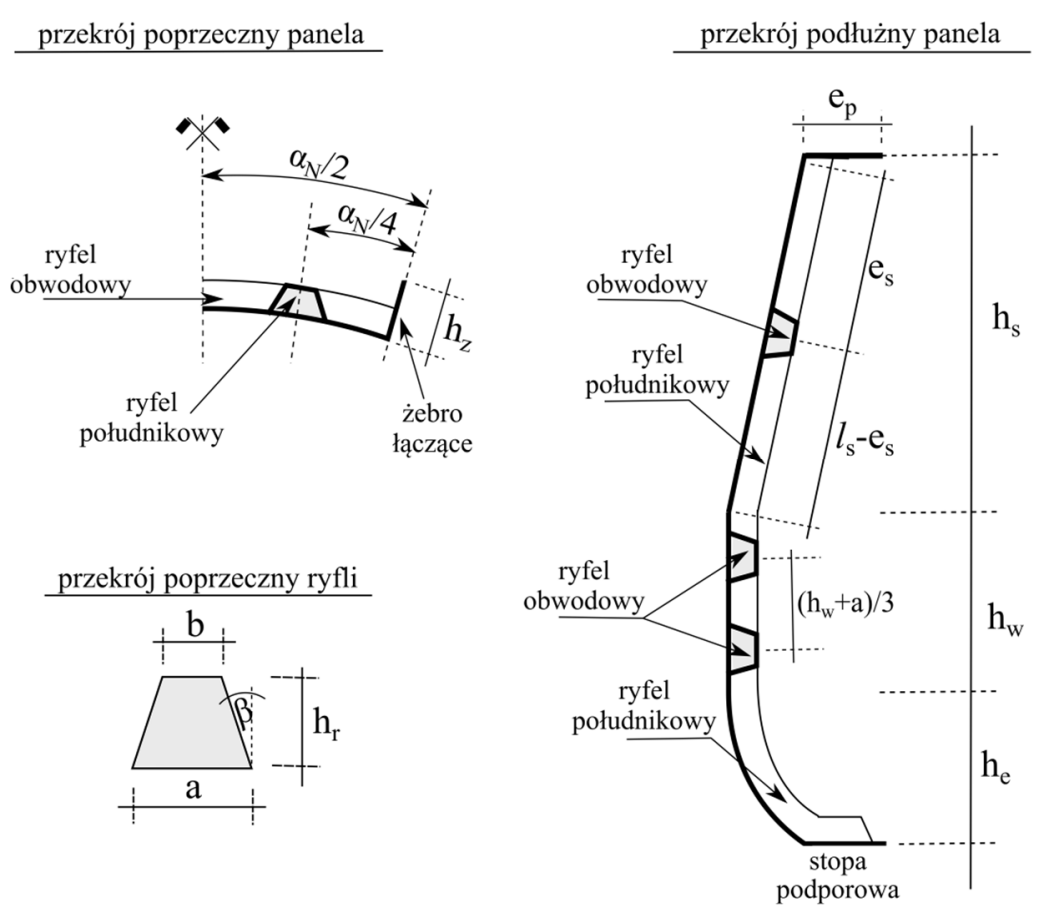

Rys. 4. Przekroje poprzeczne panelu

Fig. 4. Cross sections of a panel

\section{Parametryzacja kształtu i grubości powłok dyfuzora}

Parametry determinujące własności dynamiczne dyfuzora podzielono na te określające kształt oraz grubość powłoki. Przez kształt rozumie się tu jedynie zewnętrzny obrys konstrukcji a nie kształt tworzącej wewnętrznej. Ostatecznie przyjęto, że parametrami swobodnymi określającymi kształt są (Rys. 4):

- $\mathrm{e}_{\mathrm{p}}$ - szerokość pierścienia górnego,

- $e_{s}$ - lokalizacja ryfla obwodowego na części stożkowej (wylotowej),

- a - szerokość podstawy przekroju poprzecznego ryfli obwodowych i podłużnych,

- $\mathrm{h}_{\mathrm{r}}$ - wysokość przekroju poprzecznego ryfli obwodowych i podłużnych. 
Pozostałe wielkości określające kształt dyfuzora są dane lub można je wyliczyć jako funkcje wielkości danych i parametrów swobodnych (zob. poprzedni rozdział).

Grubość powłoki dyfuzora wynika z technologii wykonywania paneli. Tutaj założono, że powłoka każdego panelu składa się z dwóch części (Rys. 5): 1 powłoki wewnętrznej wykonywanej ze stałą grubością $t_{\text {wew }}=4 \mathrm{~mm}$ (prócz pierścienia górnego, którego grubość wynosi $\mathrm{t}_{\mathrm{pw}}$ ) oraz $2^{\circ}$ doklejanej do niej powłoki zewnętrznej, w której ukształtowano ryfle obwodowe i południkowe. Sklejenia następują w miejscach styku obu powłok (żebra łączące panele, powierzchnie pomiędzy ryflami, pierścień górny, stopa), natomiast obszary, gdzie obie powłoki się nie sklejają to: podstawy ryfli i ich ścianki. Zakłada się, że grubość warstwy kleju jest stała i wynosi $t_{k}=1.5 \mathrm{~mm}$. Podobnie można przyjąć, że w obszarach klejenia obu powłok, powłoka zewnętrzna ma stałą grubość $t_{\text {zew }}=3 \mathrm{~mm}$ (prócz pierścienia stopy podporowej, której grubość wynosi $\mathrm{t}_{\mathrm{st}}=5 \mathrm{~mm}$ ). Ostatecznie przyjęto, że parametrami swobodnymi pozostają wyłącznie (Rys. 5):

- $\mathrm{t}_{\mathrm{rp}}$ - grubość ścian ryfli podłużnych,

- $\mathrm{t}_{\mathrm{rs}}$ - grubość ścian ryfla obwodowego w części stożkowej,

- $\mathrm{t}_{\mathrm{rw}}$ - grubość ścian ryfli obwodowych w części walcowej,

- $t_{p w}$ - grubość powłoki wewnętrznej pierścienia górnego.

Zatem np. sumaryczna grubość powłoki w miejscach sklejenia wynosi $t_{w e w}+t_{k}+$ $+t_{\text {zew }}$, dla pierścienia $t_{p w}+t_{k}+t_{\text {zew }}$, dla żebra łączącego panele $t_{w e w}+t_{k}+t_{z e w}$ itd.

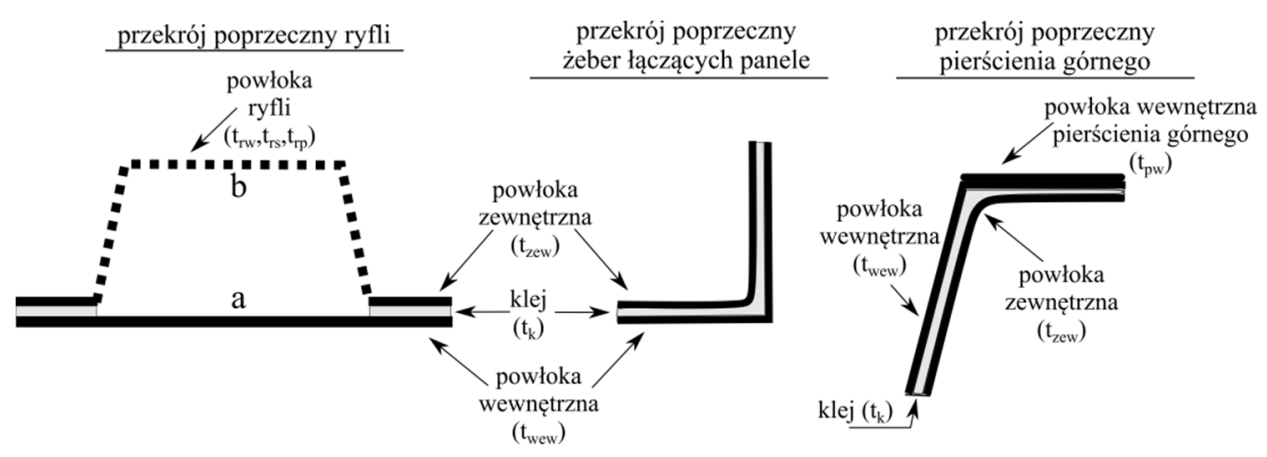

Rys. 5. Grubości powłok panelu

Fig. 5. Thicknesses of the shells in a panel

Wymienione parametry dyfuzora przyjmują określone wartości dyskretne ze zbioru liczb rzeczywistych - zestawiono je w tabeli 1 . Wartości te wynikają m.in. z technologii wykonania i typizacji form wytwórczych; są również, w pewnym zakresie, niezależne od podstawowych wymiarów geometrycznych (takich jak $R_{w}, R_{e}, R_{s}, h_{w}, h_{e}, h_{s}$ ). Parametrom fizycznym przyporządkowano nazwy parametrów matematycznych (tabela 1.), które uporządkowano w postaci wektora $\mathbf{x}=\left[\mathrm{x}_{1}, \ldots, \mathrm{x}_{8}\right]$. 
Tabela 1. Dyskretne wartości przyjmowane przez parametry

Table 1. Discrete values sets of parameters

\begin{tabular}{|c|c|c|}
\hline \multicolumn{2}{|c|}{ Parametr } & \multirow{2}{*}{$\begin{array}{c}\text { Zbiory wartości przyjmowane } \\
\text { przez parametry oraz kody grubości powłoki }\end{array}$} \\
\hline $\begin{array}{c}\text { nazwa } \\
\text { matematyczna }\end{array}$ & $\begin{array}{c}\text { nazwa } \\
\text { fizyczna }\end{array}$ & \\
\hline $\mathrm{X}_{1}$ & $e_{p}$ & $0.2 ; 0.25 ; 0.3 ; 0.35 ; 0.4[\mathrm{~m}]$ \\
\hline $\mathrm{x}_{2}$ & $\mathrm{e}_{\mathrm{s}}$ & $0.5 ; 1.0 ; 1.5 ; 2.0 ; 2.5,3.0,3.5[\mathrm{~m}]$ \\
\hline $\mathrm{x} 3$ & $\mathrm{a}$ & $0.10 ; 0.15 ; 0.20 ; 0.25[\mathrm{~m}]$ \\
\hline $\mathrm{X}_{4}$ & $\mathrm{~h}_{\mathrm{r}}$ & $0.05 ; 0.10 ; 0.15 ; 0.20[\mathrm{~m}]$ \\
\hline $\mathrm{X} 5$ & $t_{\text {rp }}$ & $\begin{array}{l}4 ; 6 ; 8[\mathrm{~mm}] \\
(1) ;(2) ;(3) \text { - wartość kodowa; poz. } 1\end{array}$ \\
\hline $\mathrm{X} 6$ & $\operatorname{trs}$ & $\begin{array}{l}4 ; 6 ; 8[\mathrm{~mm}] \\
(1) ;(2) ;(3) \text { - wartość kodowa; poz. } 2\end{array}$ \\
\hline $\mathrm{x}_{7}$ & $\mathrm{t}_{\mathrm{rw}}$ & $\begin{array}{l}4 ; 6 ; 8[\mathrm{~mm}] \\
(1) ;(2) ;(3) \text { - wartość kodowa; poz. } 3\end{array}$ \\
\hline X8 & $t_{\mathrm{pw}}$ & $\begin{array}{l}5 ; 10 ; 15 ; 20 ; 25[\mathrm{~mm}] \\
(1) ;(2) ;(3) ;(4) ;(5) \text { - wartość kodowa; poz. } 4\end{array}$ \\
\hline
\end{tabular}

W celu parametryzacji i automatyzacji generacji modelu i późniejszych obliczeń opracowano program w języku Visual Basic Script, będącego podstawą LPI (Lusas Program Interface) - wewnętrznego środowiska programistycznego programu LUSAS FEA (zob. [8]).

Zasadnicza trudność w sformułowaniu jednolitych formuł przybliżonych (np. wielomianowych) na funkcje częstotliwości drgań własnych $f_{i}(\mathbf{x})$ polega na tym, że przy zmianie parametrów następuje często zmiana kolejności częstotliwości drgań własnych i kształtu postaci. Z kolei kształt postaci ma znaczenie, gdy liczba fal obwodowych pokrywa się z liczbą łopat śmigła - jest to sytuacja bardzo niekorzystna z punktu widzenia wzbudzanych amplitud drgań.

$\mathrm{W}$ dalszym ciągu tekstu, w odniesieniu do parametrów grubości $\mathrm{x}_{5} \div \mathrm{x}_{8}$, będzie stosowany zapis kodowy: każda cyfra kodu oznacza koleją wartość parametru ze zbioru - patrz tabela 1 . Pierwsza cyfra kodu (pierwsza pozycja) odpowiada parametrowi $\mathrm{x}_{5}$, ostatnia - parametrowi $\mathrm{x}_{8}$. Zatem na przykład kod 1234 oznacza następujące grubości: $t_{\mathrm{rp}}=4 \mathrm{~mm}, \mathrm{t}_{\mathrm{rs}}=6 \mathrm{~mm}, \mathrm{t}_{\mathrm{rw}}=8 \mathrm{~mm}, \mathrm{t}_{\mathrm{pw}}=20 \mathrm{~mm}$. Wyodrębnienie parametrów określających grubości powłok jest uzasadnione łatwiejszym algorytmem modyfikacji modelu MES niż w przypadku parametrów kształtu, których zmiana pociąga za sobą konieczność regeneracji geometrii modelu.

\section{Materiały}

Obie powłoki dyfuzora wykonuje się w dwu różnych otwartych formach: wewnętrznej i zewnętrznej, metodą laminowania ręcznego (kontaktowego) lub natrysku. Kolejne warstwy laminatu składają się z mat z włókna szklanego i matrycy na bazie żywic poliestrowych. Można przyjąć, że powstające warstwy ma- 
ją cechy izotropowe i jednorodne. Odmienne cechy mechaniczne posiada warstwa kleju, do której dodaje się czasem rozdrobnione odpady produkcyjne. Poniżej, w tabeli 2 zestawiono przyjęte w analizie własności materiałów $[6,7]$.

Tabela 2. Własności mechaniczne materiałów

Table 2. Properties of materials used in analysis

\begin{tabular}{|c|c|c|c|}
\hline \multirow{2}{*}{ Warstwa } & \multicolumn{3}{|c|}{ Własności mechaniczne } \\
\cline { 2 - 4 } & $\begin{array}{c}\text { moduł E } \\
{[\mathrm{GPa}]}\end{array}$ & $\begin{array}{c}\text { wsp. Poissona } \\
{[-]}\end{array}$ & $\begin{array}{c}\text { gęstość } \\
{\left[\mathrm{kg} / \mathrm{m}^{3}\right]}\end{array}$ \\
\hline Kompozyt & 12.0 & 0.25 & 1650 \\
\hline Klej & 8.0 & 0.25 & 1500 \\
\hline
\end{tabular}

\section{Opis modelu MES i procedury obliczeniowej}

Model elementów skończonych zbudowano w programie LUSAS FEA [8] z wykorzystaniem modułu Composite. Geometrię powłok dyfuzora odtworzono w powierzchniach środkowych - zastosowano powłokowe czterowęzłowe elementy skończone QTS4 (element ten może ulegać degradacji do elementu 3-węzłowego gdy węzły k-1 pokrywają się). Jest to element powłoki cienkiej z 5-cioma stopniami swobody w węźle. Po powierzchni element ma 4 punkty całkowania Gaussa, natomiast po grubości punkt całkowania zlokalizowany jest w środku warstwy - Rys. 6.

Po grubości powłok zewnętrznej i wewnętrznej zdefiniowano 3 warstwy, natomiast grubość kleju stanowi pojedynczą warstwę - Rys. 7.

W modelu obliczeniowym założono pełne złączenie paneli na całej długości żeber łączących - zatem przenoszony jest tu komplet sił przekrojowych. Kinematyczne warunki brzegowe obejmują węzły krawędzi wewnętrznej stopy, które mają odebrany ruch pionowy - Rys. 8; natomiast w miejscach przykręcenia stopy do stropu odebrano przemieszczenia pionowe, radialne i styczne (zamocowania przegubowe). Takie zamocowanie stopy powoduje pewien efekt utwierdzenia elipsoidy w stropie obserwowany w rzeczywistości.
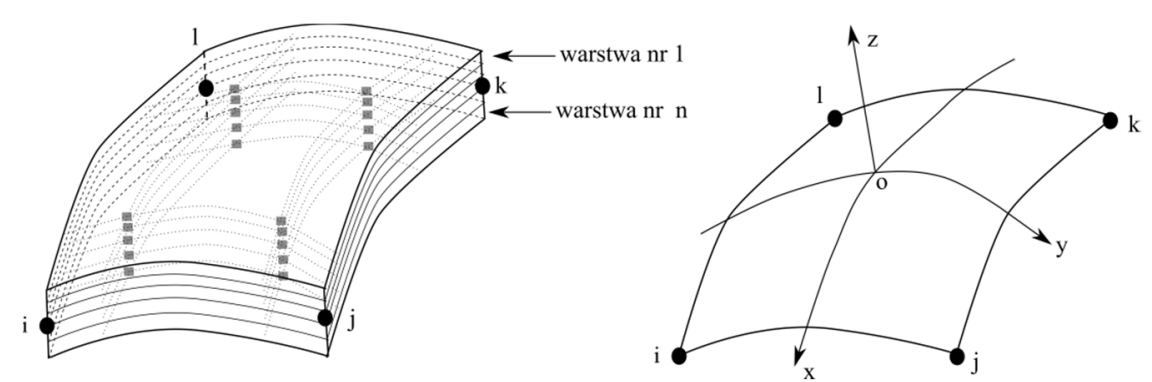

Rys. 6. Geometria i uwarstwienie elementu QTS4

Fig. 6. Geometry and layup of finite element QTS4 


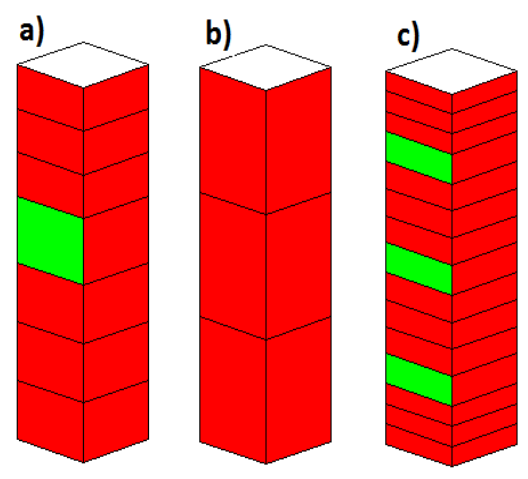

Klej Kompozyt

Rys. 7. Wizualizacja układu warstw (grubość została znormalizowana do jedynki): a) sklejona powłoka zewnętrzna i wewnętrzna, b) powłoka zewnętrzna, c) układ warstw na żebrze łączącym panele

Fig. 7. Visualization of composite layup (thickness normalized to one): a) glued of internal and external shells, b) external shell only, c) composite layup in ribbon joining of the panels

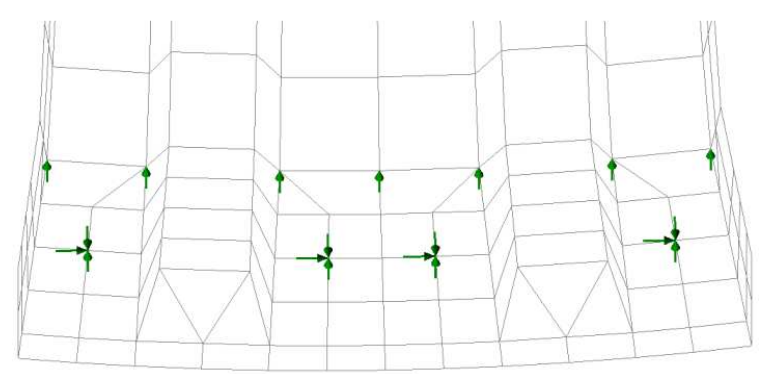

Rys. 8. Wizualizacja przyjętych warunków brzegowych na stopie panelu

Fig. 8. Visualization of a boundary conditions in the foot of the panel

Globalny układ współrzędnych przyjęto tak, że oś dyfuzora stanowi oś Z globalnego układu współrzędnych, natomiast osie X i Y (płaszczyzna OXY) leżą w płaszczyźnie stopy dyfuzora.

Na Rys. 9 pokazano siatkę elementów skończonych w obrębie połówki jednego panelu (panel jest symetryczny względem tworzącej w środku panelu); kolorami zaznaczono grupy elementów.

W obliczeniach zadania własnego użyto algorytmu iteracji podprzestrzennej (Subspace Iteration) przy $n=100$ wektorach początkowych i zadanym błędzie iteracji równym $\delta=1 \mathrm{e}-6$. Włączono także weryfikację Sturma [8]. Względnie duża liczba $n$ wektorów początkowych jest wymagana z uwagi na obecność podwójnych częstotliwości własnych. Algorytm rozwiązania zadania własnego ustawiono na poszukiwanie 10 najmniejszych częstotliwości i postaci własnych bez uwzględnienia tłumienia. 

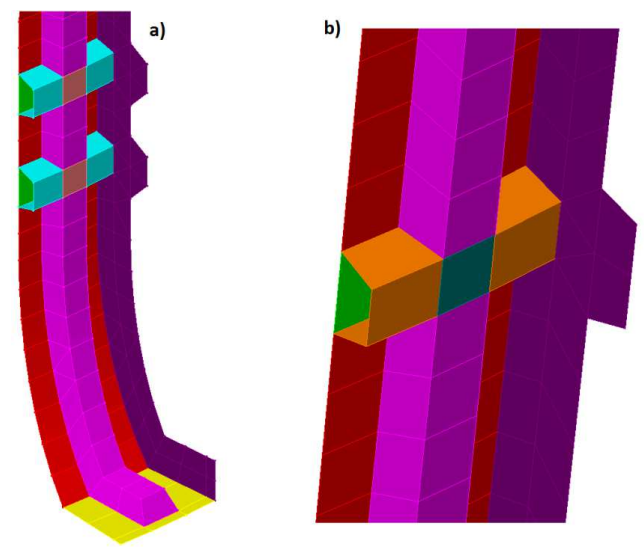

Rys. 9. Siatka MES w obrębie połówki jednego panelu: a) część eliptyczna i walcowa, b) widok ryfla obwodowego w części stożkowej

Fig. 9. Finite element mesh of one-half of a panel: a) elliptical and cylindrical parts, b) view of the ribbon into cone part

\section{Analiza wpływu parametrów na częstotliwości i postacie drgań własnych}

Na Rys. 10 przedstawiono typowe postacie drgań powłoki dyfuzora - nie zachowano kolejności uporządkowania wg najmniejszej częstotliwości drgań. Kolejność częstotliwości własnych (kształtów postaci) uporządkowanych rosnąco jest zależna przede wszystkim od relacji sztywności pierścienia górnego, żeber łączących panele i sztywności ryfli (obwodowego w części stożkowej i podłużnych) - w mniejszym zakresie odgrywają tu rolę relacje masowe. Na Rys. 10a) $\div$ d) pokazano postacie powłokowe, natomiast postać e) jest typu wspornikowego, zaś Rys. 10f) obrazuje postać skrętną. Wspomniane postacie powłokowe związane są z obecnością pełnych okresów fal obwodowych. $\mathrm{Na}$ Rys. 10a):d) widać odpowiednio 2, 3, 4, 5 pełnych okresów.

Na kolejnych Rys. 11a $\div 11$ f oraz Rys. 12 do Rys. 16 pokazano przebiegi funkcji pierwszych (najmniejszych) czterech częstotliwości drgań własnych $f_{1}(\mathbf{x}) \div f_{4}(\mathbf{x})$ w zależności od zmienności wybranych parametrów. Na wszystkich rysunkach osie pionowe przedstawiają wartości częstotliwości w Hz. Natomiast na Rys. 11 do Rys. 14 osie poziome obrazują zmianę poszczególnych grubości wyrażone w postaci kodu, dodatkowy opis nad wykresami uwidacznia wartości pozostałych parametrów. Rysunki 15 i 16 obrazują funkcje częstotliwości względem odpowiednio parametru $e_{s} i e_{p}$ przy ustalonych pozostałych parametrach - opisy nad rysunkami. W celu zobrazowania kształtu postaci odpowiadających poszczególnym częstotliwościom przy punktach charakterystycznych podano liczbę fal obwodowych danej postaci lub literę "w" oznaczającą postać wspornikową drgań powłoki (zob. też Rys. 10e). 

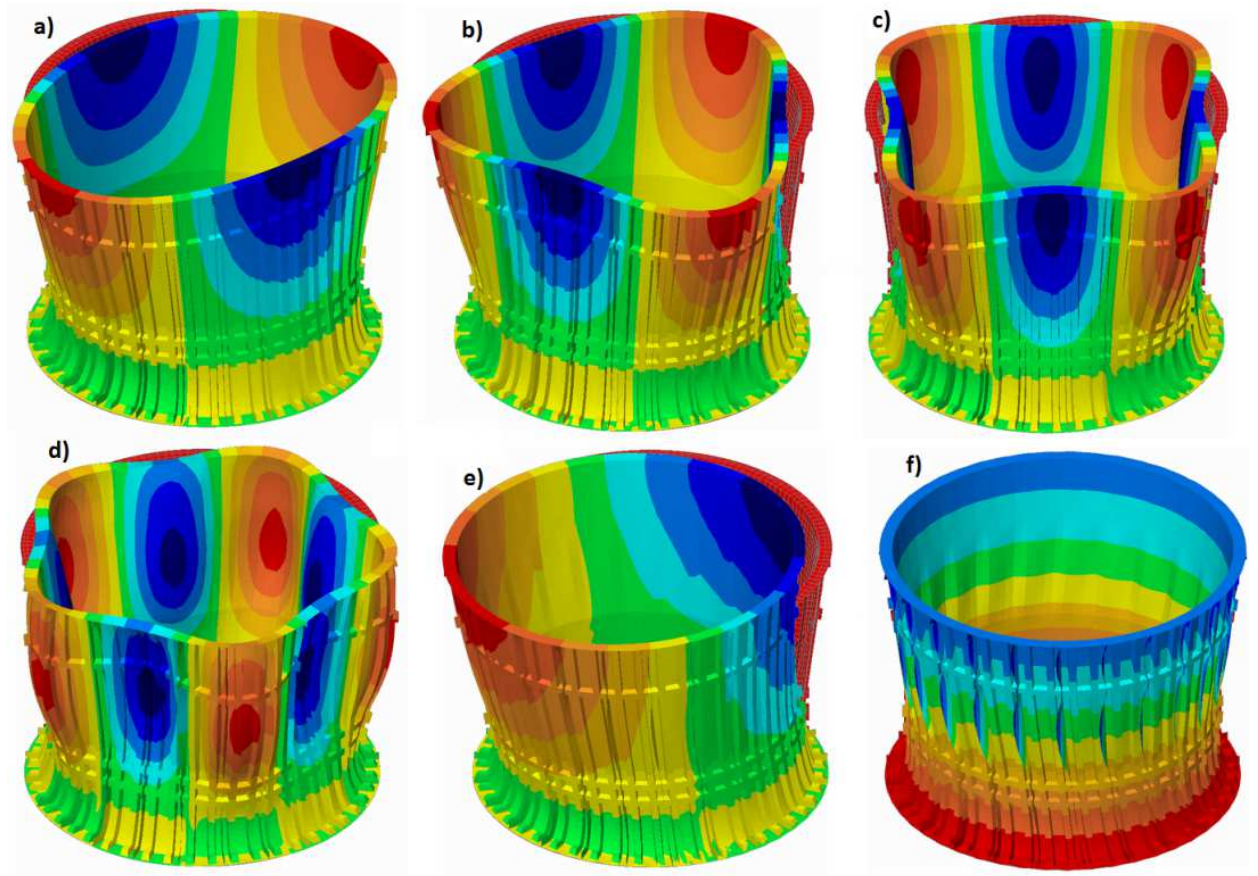

Rys. 10. Wizualizacja typowych kształtów postaci drgań własnych

Fig. 10. Visualization of typical modeshapes

$e_{p}=0.2 m ; e_{s}=1.5 m ; a=0.1 m ; h_{r}=0.05 m \quad e_{p}=0.35 m ; e_{s}=1.5 m ; a=0.25 m ; h_{r}=0.2 m$
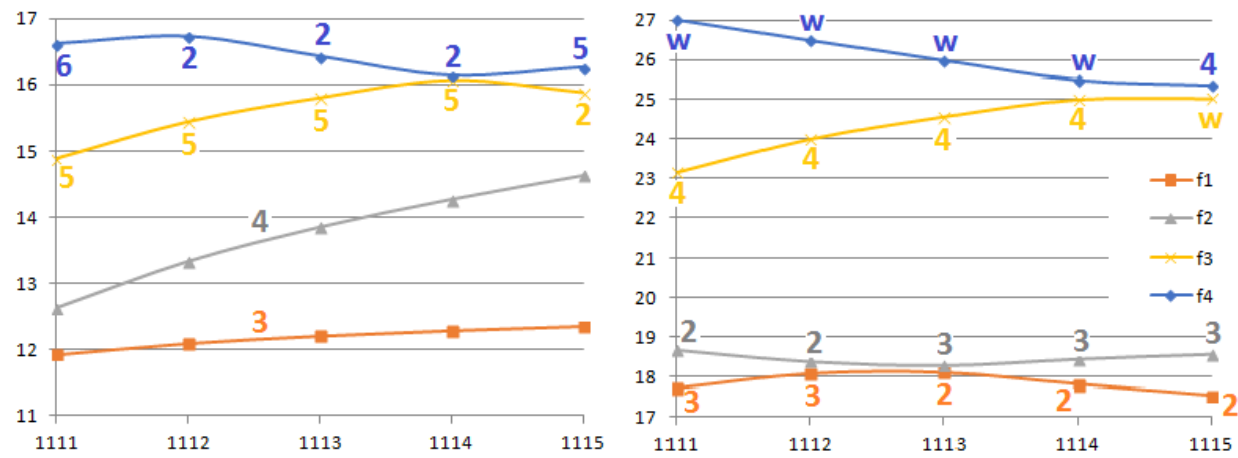

Rys. 11a. Funkcje częstotliwości drgań własnych $f_{1} \div f_{4}[\mathrm{~Hz}]$ przy zmianie parametru tpw

Fig. 11a. Function of eigenfrequencies $f_{1} \div f_{4}[\mathrm{~Hz}]$ due to change of thickness $\mathrm{t}_{\mathrm{pw}}$ 
$\mathrm{e}_{\mathrm{p}}=0.2 \mathrm{~m} ; \mathrm{e}_{\mathrm{s}}=1.5 \mathrm{~m} ; \mathrm{a}=0.1 \mathrm{~m} ; \mathrm{h}_{\mathrm{r}}=0.05 \mathrm{~m}$

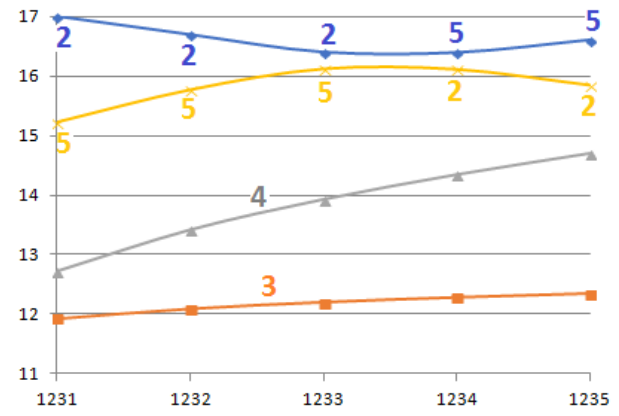

$\mathrm{e}_{\mathrm{p}}=0.35 \mathrm{~m} ; \mathrm{e}_{\mathrm{s}}=1.5 \mathrm{~m} ; \mathrm{a}=0.25 \mathrm{~m} ; \mathrm{h}_{\mathrm{r}}=0.2 \mathrm{~m}$

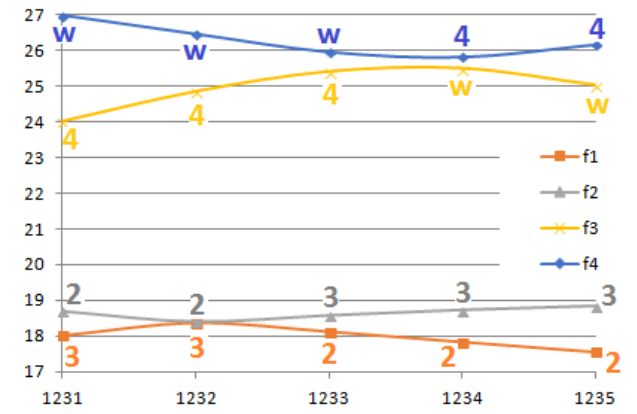

Rys. 11b. Funkcje częstotliwości drgań własnych $f_{1} \div f_{4}[\mathrm{~Hz}]$ przy zmianie parametru tpw

Fig. 11b. Function of eigenfrequencies $f_{1} \div f_{4}[\mathrm{~Hz}]$ due to change of thickness $\mathrm{t}_{\mathrm{pw}}$

$e_{p}=0.2 m ; e_{s}=1.5 m ; a=0.1 m ; h_{r}=0.05 m$

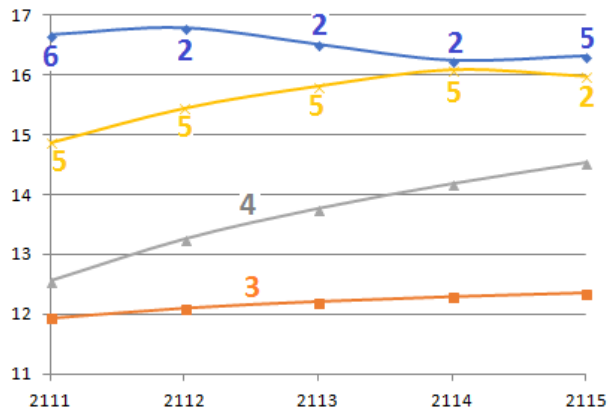

$\mathrm{e}_{\mathrm{p}}=0.35 \mathrm{~m} ; \mathrm{e}_{\mathrm{s}}=1.5 \mathrm{~m} ; \mathrm{a}=0.25 \mathrm{~m} ; \mathrm{h}_{\mathrm{r}}=0.2 \mathrm{~m}$

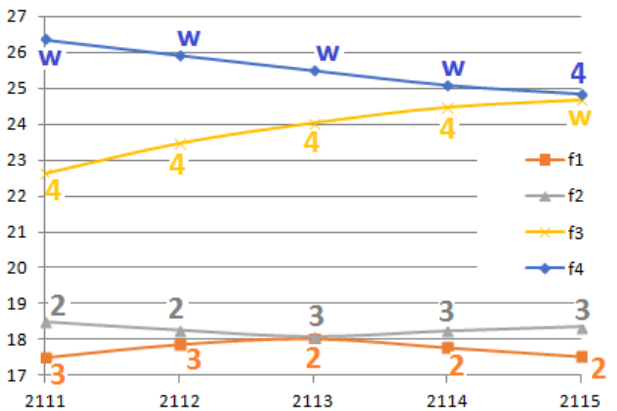

Rys. 11c. Funkcje częstotliwości drgań własnych $f_{1} \div f_{4}[\mathrm{~Hz}]$ przy zmianie parametru tpw

Fig. 11c. Function of eigenfrequencies $f_{1} \div f_{4}[\mathrm{~Hz}]$ due to change of thickness $\mathrm{t}_{\mathrm{pw}}$
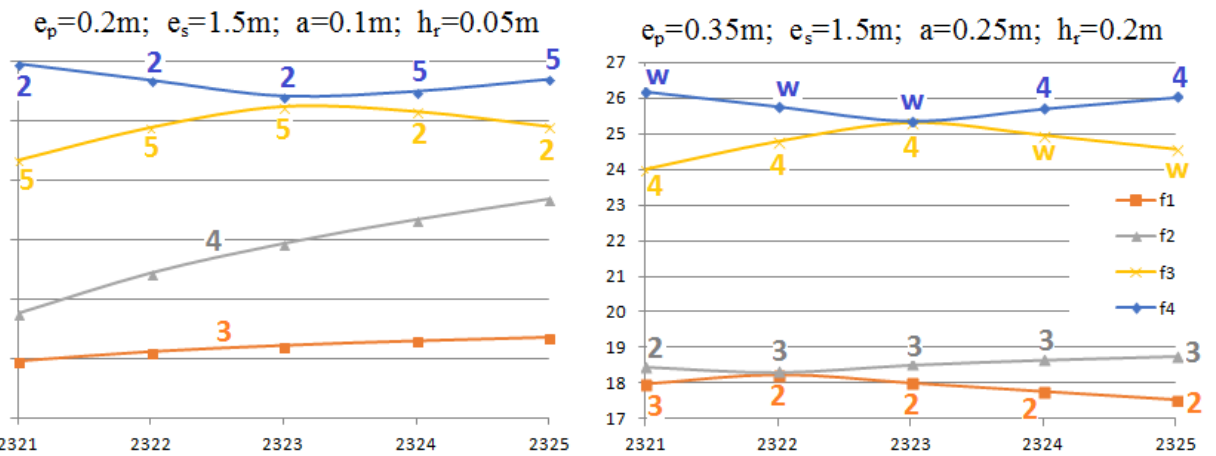

Rys. 11d. Funkcje częstotliwości drgań własnych $f_{1} \div f_{4}[\mathrm{~Hz}]$ przy zmianie parametru tpw

Fig. 11d. Function of eigenfrequencies $f_{1} \div f_{4}[\mathrm{~Hz}]$ due to change of thickness $t_{\mathrm{pw}}$ 
$e_{p}=0.2 m ; e_{s}=1.5 m ; a=0.1 m ; h_{r}=0.05 m$
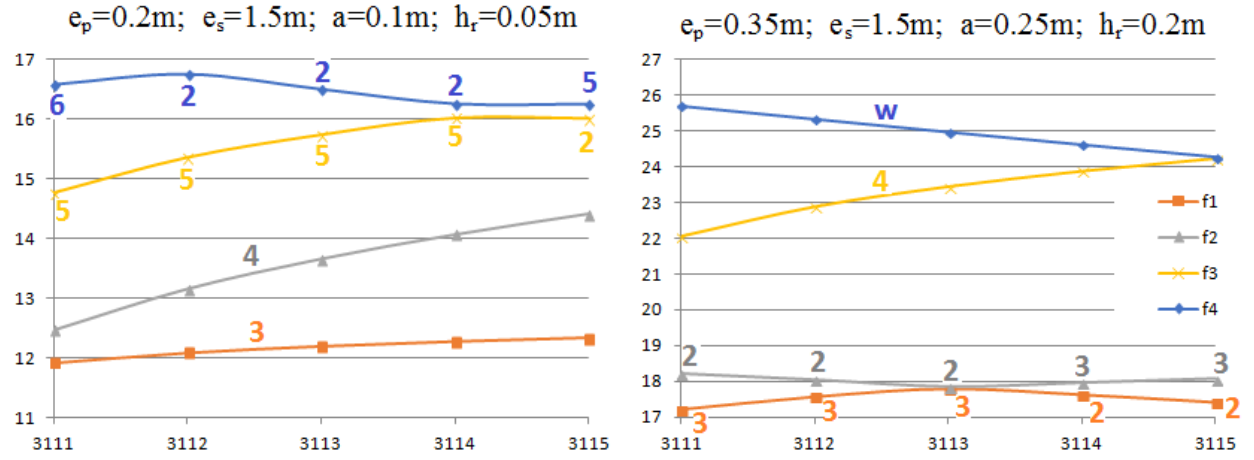

Rys. 11e. Funkcje częstotliwości drgań własnych $f_{1} \div f_{4}[\mathrm{~Hz}]$ przy zmianie parametru tpw

Fig. 11e. Function of eigenfrequencies $f_{1} \div f_{4}[\mathrm{~Hz}]$ due to change of thickness $\mathrm{t}_{\mathrm{pw}}$

$\mathrm{e}_{\mathrm{p}}=0.2 \mathrm{~m} ; \mathrm{e}_{\mathrm{s}}=1.5 \mathrm{~m} ; \mathrm{a}=0.1 \mathrm{~m} ; \mathrm{h}_{\mathrm{r}}=0.05 \mathrm{~m}$

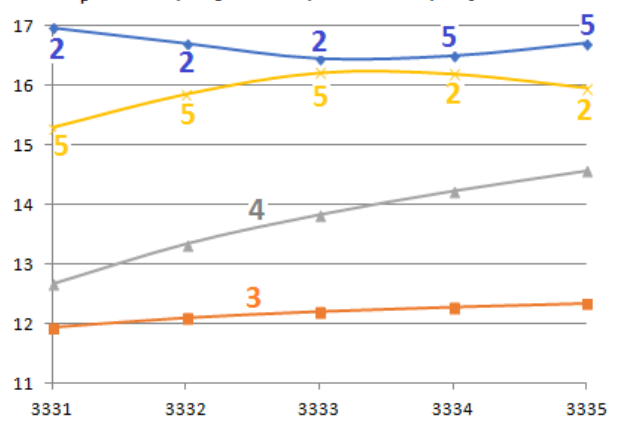

$\mathrm{e}_{\mathrm{p}}=0.35 \mathrm{~m} ; \mathrm{e}_{\mathrm{s}}=1.5 \mathrm{~m} ; \mathrm{a}=0.25 \mathrm{~m} ; \mathrm{h}_{\mathrm{r}}=0.2 \mathrm{~m}$

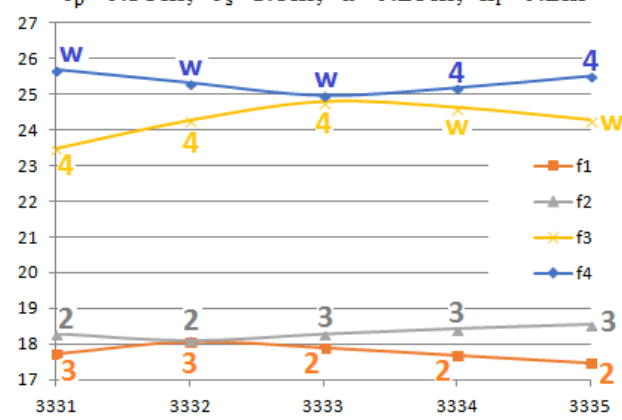

Rys. 11f. Funkcje częstotliwości drgań własnych $f_{1} \div f_{4}[\mathrm{~Hz}]$ przy zmianie parametru $\mathrm{t}_{\mathrm{pw}}$

Fig. 11f. Function of eigenfrequencies $f_{1} \div f_{4}[\mathrm{~Hz}]$ due to change of thickness $\mathrm{t}_{\mathrm{pw}}$

$\mathrm{e}_{\mathrm{p}}=0.2 \mathrm{~m} ; \mathrm{e}_{\mathrm{s}}=1.5 \mathrm{~m} ; \mathrm{a}=0.1 \mathrm{~m} ; \mathrm{h}_{\mathrm{r}}=0.05 \mathrm{~m}$

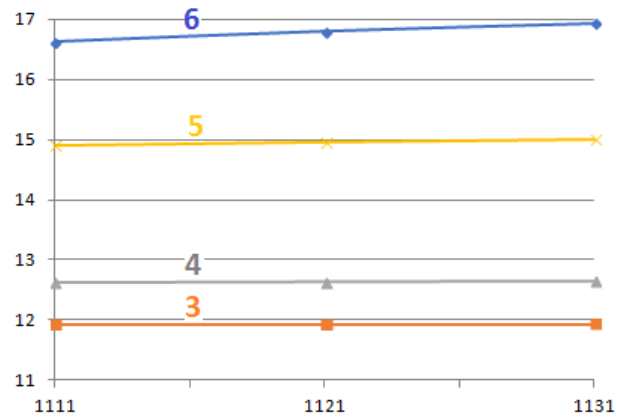

$\mathrm{e}_{\mathrm{p}}=0.35 \mathrm{~m} ; \mathrm{e}_{\mathrm{s}}=1.5 \mathrm{~m} ; \mathrm{a}=0.25 \mathrm{~m} ; \mathrm{h}_{\mathrm{r}}=0.2 \mathrm{~m}$

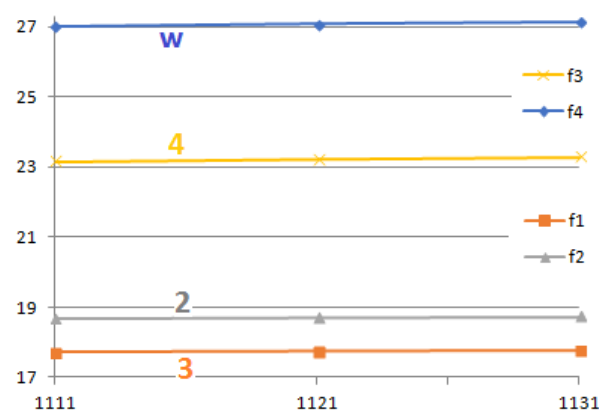

Rys. 12. Funkcje częstotliwości drgań własnych $f_{1} \div f_{4}[\mathrm{~Hz}]$ przy zmianie parametru trw

Fig. 12. Function of eigenfrequencies $f_{1} \div f_{4}[\mathrm{~Hz}]$ due to change of thickness $t_{\mathrm{rw}}$ 

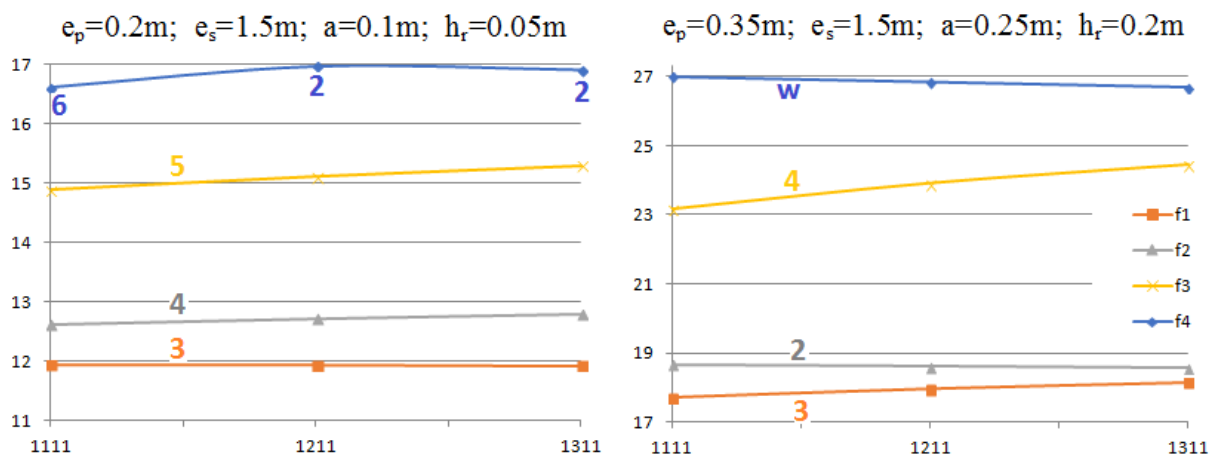

Rys. 13. Funkcje częstotliwości drgań własnych $f_{1} \div f_{4}[\mathrm{~Hz}]$ przy zmianie parametru trs

Fig. 13. Function of eigenfrequencies $f_{1} \div f_{4}[\mathrm{~Hz}]$ due to change of thickness $\mathrm{t}_{\mathrm{rs}}$
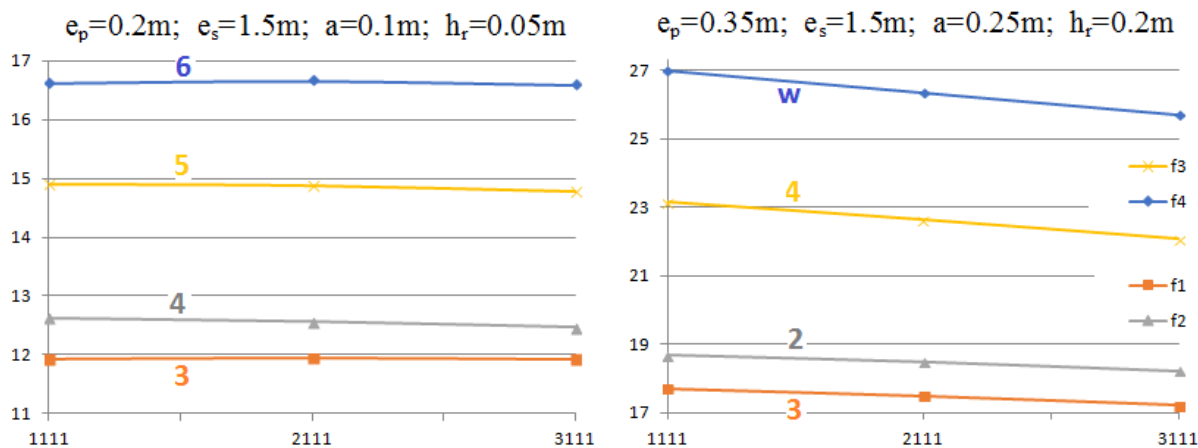

Rys. 14. Funkcje częstotliwości drgań własnych $f_{1} \div f_{4}[\mathrm{~Hz}]$ przy zmianie parametru $\mathrm{t}_{\mathrm{rp}}$

Fig. 14. Function of eigenfrequencies $f_{1} \div f_{4}[\mathrm{~Hz}]$ due to change of thickness $\mathrm{t}_{\mathrm{rp}}$

$\operatorname{kod}=1111$

$\mathrm{e}_{\mathrm{p}}=0.2 \mathrm{~m} ; \mathrm{a}=0.1 \mathrm{~m} ; \mathrm{h}_{\mathrm{r}}=0.05 \mathrm{~m}$

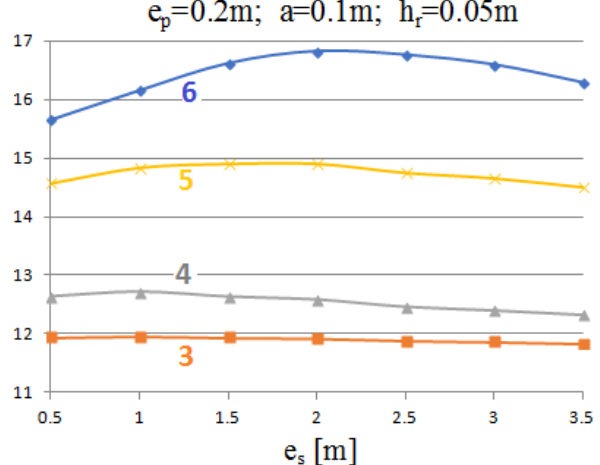

$\operatorname{kod}=1111$

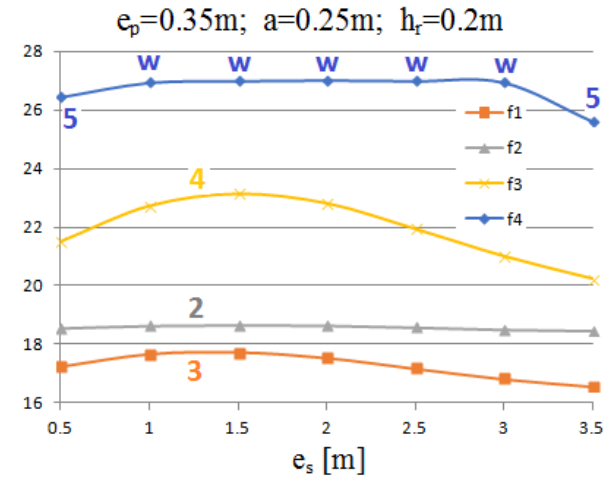

Rys. 15. Funkcje częstotliwości drgań własnych $f_{1} \div f_{4}[\mathrm{~Hz}]$ przy zmianie parametru es

Fig. 15. Function of eigenfrequencies $f_{1} \div f_{4}[\mathrm{~Hz}]$ due to change of parameter es 


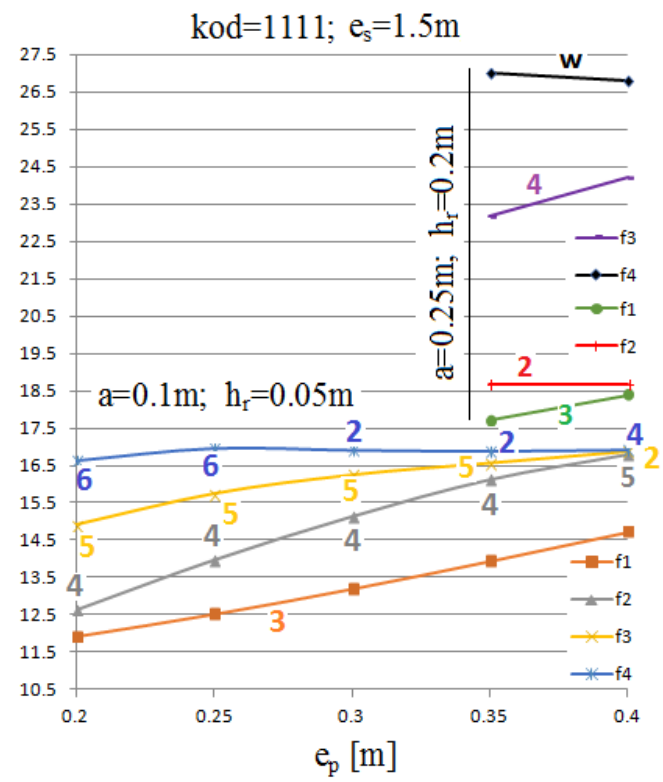

Rys. 16. Funkcje częstotliwości drgań własnych $f_{1} \div f_{4}[\mathrm{~Hz}]$ przy zmianie parametru $\mathrm{e}_{\mathrm{p}}$

Fig. 16. Function of eigenfrequencies $f_{1} \div f_{4}[\mathrm{~Hz}]$ due to change of parameter $\mathrm{e}_{\mathrm{p}}$

Rysunki $11 \mathrm{a} \div 11 \mathrm{f}$ pokazują funkcje $f_{1}\left(\mathrm{t}_{\mathrm{pw}}\right) \div f_{4}\left(\mathrm{t}_{\mathrm{pw}}\right)$ przy zmianie $\mathrm{t}_{\mathrm{pw}}$ i ustalonych pozostałych parametrach. Analiza tych wykresów wskazuje, że dla wartości parametrów geometrycznych $\mathrm{w}$ zakresie niskich wartości z ich zbiorów zmienności (wykresy po lewej stronie), pierwsze dwie postacie $f_{1}$ i $f_{2}$ są związane odpowiednio z trzema maksimami obwodowymi i czterema. Kolejna trzecia częstotliwość $f_{3}$ jest najczęściej związana $\mathrm{z}$ pięcioma maksimami, jednak w przypadkach dużych grubości pierścienia górnego $\mathrm{t}_{\mathrm{pw}}=20 \mathrm{~mm}$ i $\mathrm{t}_{\mathrm{pw}}=25 \mathrm{~mm}$, czyli zwiększonej jego sztywności, częstotliwość $f_{3}$ jest związana z dwoma maksimami obwodowymi, a postać $f_{4} \mathrm{z}$ pięcioma - następuje tu zmiana kolejności kształtów postaci.

Z kolei analiza Rys. 11a $\div 11$, sporządzona dla zwiększonej szerokości pierścienia górnego i sztywności ryfli (wykresy po prawej stronie), wskazuje na znacznie bardziej skomplikowane relacje pomiędzy postaciami drgań. Generalnie częstotliwości mają nominalnie wyższe wartości; ponadto pierwsza $f_{1}$ i druga $f_{2}$ leżą bliżej siebie i jednocześnie są bardziej odseparowane od trzeciej $f_{3}$ i czwartej $f_{4}$. Istotne jest również to, że pierwsze dwie częstotliwości odpowiadają trzem i dwóm falom po obwodzie (inaczej niż poprzednio) i następuje tu zmiana kolejności kształtów postaci przy wzroście $t_{\text {pw }}$. Postać z czterema falami stała się trzecią częstotliwością, która zamienia kolejność z postacią wspornikową. Brak jest zatem postaci z pięcioma falami obwodowymi w zakresie $f_{1} \div f_{4}$. 
Rysunki $12,13,14$ pokazują funkcje $f_{1} \div f_{4}$ odpowiednio względem parametrów $t_{r w}, t_{r s}, t_{r p} i$ przy ustalonych pozostałych parametrach. Widać, że zmiana tych parametrów nie wywołuje istotnych zmian wartości częstotliwości drgań własnych, nie ma tu też zamiany kolejności postaci. Podobnie jak poprzednio zwiększenie sztywności pierścienia górnego powoduje pojawienie się postaci wspornikowej $f_{4}$.

Rysunek 15 pokazuje funkcje $f_{1}\left(\mathrm{e}_{\mathrm{s}}\right) \div f_{4}\left(\mathrm{e}_{\mathrm{s}}\right)$ względem parametru $\mathrm{e}_{\mathrm{s}}$ i przy ustalonych pozostałych parametrach. Widać, że zmiana tego parametru wywołuje przebieg funkcji z zaznaczonym ekstremum (pomiędzy $e_{s}=1 \mathrm{~m}$ a $e_{s}=2 \mathrm{~m}$ ). Jest ono wyraźniejsze przy wyższych częstotliwościach i większej sztywności pierścienia górnego.

Ostatni Rys. 16 pokazuje funkcje $f_{1}\left(\mathrm{e}_{\mathrm{p}}\right) \div f_{4}\left(\mathrm{e}_{\mathrm{p}}\right)$ względem parametru e $\mathrm{e}$ i przy ustalonych pozostałych parametrach. Widać, że zmiana tego parametru wywołuje relatywnie największe zmiany wartości częstotliwości $f_{1} \div f_{4}$ przy niskich wartościach pozostałych parametrów, w szczególności sztywności ryfli (parametry $\mathrm{a}=0.1 \mathrm{~m}, \mathrm{~h}_{\mathrm{r}}=0.05 \mathrm{~m}$ ). Ponadto zwiększenie szerokości pierścienia ponad wartość $\mathrm{e}_{\mathrm{s}}=0.35 \mathrm{~m}$ powoduje zbliżenie się $f_{2}, f_{3}, f_{4}$. Zwiększenie sztywności ryfli (parametry $\mathrm{a}=0.25 \mathrm{~m}, \mathrm{~h}_{\mathrm{r}}=0.2 \mathrm{~m}$ ) powoduje zwiększenie nominalnych wartości częstotliwości i pojawienie się postaci wspornikowej $f_{4}$.

\section{Wnioski}

Analiza postaci drgań własnych dyfuzorów jest złożona z uwagi na występowanie podwójnych częstotliwości drgań, a także ze względu na zmianę kolejności kształtów postaci drgań. Zdarza się więc, że podwójne częstotliwości drgań pokrywają się - tworząc przypadki poczwórnej częstotliwości z jakościowo innymi kształtami postaci.

Zasadniczym elementem konstrukcyjnym decydującym o wartościach i kolejności częstotliwości, a także kształcie postaci drgań własnych analizowanego dyfuzora jest pierścień górny. Teoretycznie im więcej maksimów fal w postaci drgań tym wyższa wartość częstotliwości. Podstawowym kształtem postaci $f_{1}$ jest trzy fale po obwodzie - oznacza to, że odgrywają tu pewną rolę sztywności ryfli podłużnych; lecz przy wzroście sztywności pierścienia $\left(\mathrm{t}_{\mathrm{pw}}, \mathrm{e}_{\mathrm{p}}\right)$ podstawową częstotliwością staje postać o dwóch falach po obwodzie "wypierając" poprzednią postać na drugą pozycję $f_{2}$.

Położenie ryfla obwodowego w części stożkowej ma swoje optimum wywołując ekstrema funkcji częstotliwości własnych. Dla analizowanego dyfuzora takim położeniem jest $\mathrm{e}_{\mathrm{s}} \approx 1.5 \mathrm{~m}$.

Wpływ grubości powłok $\mathrm{t}_{\mathrm{rw}}, \mathrm{t}_{\mathrm{rs}}, \mathrm{t}_{\mathrm{rp}}$ nie wywołują istotnych zmian $\mathrm{w}$ wartościach częstotliwości drgań własnych. 


\section{Literatura}

[1] www.wentech.pl (dostęp: 14.02.2017 r.).

[2] www.uniserv.com.pl (dostęp: 14.02.2017 r.).

[3] Kwon O. Engineering Manual for Cooling Tower Axial Flow Fan. 7th edition, Daeil Aqua Co., Ltd., 1994. http://ns96.asadal.net/ daeilaqua/index2.html (dostęp: 14.02.2017 r.).

[4] Venema S. C., Lazenby C. B. New Fan Blade Tip Reduces Structural Vibration - Verification in Practise. Cooling Technology Institute Annual Conference. Houdson, Texas, 2004. https://www.cti.org (dostęp: 14.02.2017 r.).

[5] Van der Spek H. F. New Fan Blade Tip Reduces Pulsation. Cooling Technology Institute Annual Conference. San Antonio, Texas, 2003. http://ngs-hab.ru/docs/hw_aerotip.pdf (dostęp: 14.02.2017 r.).

[6] Śleziona J. Podstawy technologii kompozytów. Wydawnictwo Politechniki Śląskiej. Gliwice, 1998.

[7] German J. Podstawy mechaniki kompozytów włóknistych. Politechnika Krakowska, 2001.

[8] LUSAS v15.3. User's Manual. Theory Manual. LUSAS FEA Ltd. 2016.

[9] Zein A., Kurniadi D. Unit 1 Cooling Tower Fan Stack Replacement to Increase Cooling Tower Performance, Proceedings World Geothermal Congress 2015, Melbourne, Australia, 2015.

\section{AN SENSITIVITY OF A SHAPE AND SIZE PARAMETERS ON EIGENFREQUENCY AND EIGENMODES OF A COMPOSITE FAN STACKS}

\section{S u m m a r y}

The subject of this work is a composite laminate fan stack. These structures are used in water cooling technology. Inside the composite fan stack rotates a fan, which consists of a number of fan impellers producing a forced draft of air. Because of ease of manufacturing of the stacks, their chemical resistance and durability they are produced as a self-supporting layered FRP composite shell. A major problem of design is to reduce vibration amplitudes caused by a rotating brick pressure, which is generated by moving the tip of the fan blades. One way to reduce vibration amplitudes is appropriate tuning eigenfrequencies and eigenmode shapes of the shell in relation to excitation frequency. The aim of this study is to determine the influence of geometrical (shape) and size parameters on the natural frequency of the fan stack shell. A parametric geometry model of the shell was defined and numerical algorithm that generates a FEM model was developed. The quadratic finite elements of thin curved shell were used. Each element has composite layup. The paper presents the results of calculations, contains conclusions and an analyse of parameters determining the frequency of vibration. Obtained results can be directly used in the design of fan stack structures.

Keywords: composite fan stacks, vibration of fan stack, diffuzor FRP 